\title{
Anterolateral versus Posterior Approach in Management of Lower Dorsal and Upper Lumbar Traumatic and Pathological Spine Fractures
}

\author{
ASHRAF A. OSMAN, M.D.; MAHMOUD A. GOMAA, M.D. and MOHAMED A. HUSSEIN, M.D. \\ The Department of Neurosurgery, Faculty of Medicine, Fayoum University
}

\begin{abstract}
Background: Thoracolumbar spine fractures (traumatic \& pathological) is a common vertebral pathology we face in our clinical practice. Neurological affection may occur with spinal cord compression. Both anterolateral and posterior approaches have been used to treat the condition. The ideal approach however is still not agreed on particularly when there is neurological affection due to spinal cord compression.
\end{abstract}

Aim of Study: To compare the result of anterolateral versus posterior approach in decompression and stabilization of spine.

Study Design: Prospective comparative study.

Patients and Methods: This study was prospectively conducted on 30 patients with lower dorsal and upper lumbar spine fractures operated upon in the period from January 2016 to July 2017. In-depended student $t$-test used to compare measures of two independent groups of quantitative data. Paired $t$-test in comparing two dependent quantitative data.

Results: The results of this thesis showed that in the surgical management of thoracolumbar burst and pathological fractures, the anterolateral approach was not significantly superior to the posterior approach in terms of significant recovery of neurological function, return to work and maintaining normal life activities. To some extent the anterior approach was better than posterior approach in rapid improvement of sphincteric control in patients with incomplete cord injury with sphincteric troubles.

Conclusion: Good clinical evaluation of every case with exclusion of life threatening conditions and stabilization of the general condition of the patient is mandatory before proceeding in the definitive management of the spinal pathology.

Key Words: Thoracolumbar-Anterolateral approach-Posterior approach - Laminectomy - Corpectomy.

Correspondence to: Dr. Ashraf A. Osman, The Department of Neurosurgery, Faculty of Medicine, Fayoum University

\section{Introduction}

THE incidence of thoracolumbar spine injuries is approximately $2 \%$ to $7.5 \%$ after blunt trauma to the back. $19 \%$ to $50 \%$ of these injuries have associated neurological deficits. Even in the absence of neurological deficits, injuries to thoracolumbar spine can be associated with long term pain and disability [1]

The thoracolumbar spine is the transition point between the more rigid thoracic spine and the more flexible lumbar spine and, as a result, is predisposed to unique fracture patterns and neurological deficits. Higher prevalence of injury at the T11-L1 levels than at more proximal aspects of the thoracic spine or distal lumbar spine. Unfortunately, in adults the part of spinal cord that ends near the mechanically vulnerable thoracolumbar junction contains the primary efferents for the lumbosacral roots (conus medullaris) and hence canal encroachment can have significant neurological consequences $[2,3]$.

The general goals of surgical management of all traumatic \& pathological spinal fractures are similar: Decompression of neural elements, correction of deformities, stabilization of the spine and obtaining tissue for pathology or culture in case of pathological fractures. Achievement of these goals is intended to maximize neurological functions, allow early mobilization and rehabilitation of the patient with prevention of pain and deformities. There is a little debate that surgical intervention has far greater potential than conservative treatment to correct deformity, decompress neural structures and provide immediate stability $[4,5]$.

In general, surgery for thoracolumbar extradural compressive spine fractures can be done from a 
posterior, anterior or combined approaches, depending on the goal of the procedure. The posterior approach is familiar to all spine surgeons and is the most commonly used. Posterior pedicle screw instrumentation is a common place as the technique used for achieving rigid stability. In principle, correction of sagittal and coronal plain deformities is most easily achieved and corrected with posterior approach [6].

An anterior approach is used primarily for thoracolumbar burst fractures and pathological fractures in which corpectomy and anterior reconstruction are required either to decompress retropulsed fragments of bone directly off the ventral dura or to provide immediate reconstruction of the anterior weight-bearing column for reasons of mechanical stability. In principle, in case of severer neurological deficit as the result of a large retropulsed piece of bone, an anterior approach and corpectomy provide the most direct and ensured decompression of the neural elements for thoracolumbar burst fractures [7].

Anterior approaches to pathological infective and neoplastic spine in thoracic and thoracolumbar spine have been described with the advantages of better exposure, allowing more extensive debridement or tumourenbloc excision and better decompression of the cord and more effective bone grafting and biomechanical reconstruction [8-10].

\section{Patients and Methods}

This study was prospectively conducted on 30 patients with lower dorsal and upper lumbar traumatic and pathological spine fractures operated upon in the period from January 2016 to July 2017 in the Neurosurgery Department, Cairo University and Neurosurgery Department, Fayoum University.

\section{Inclusion criteria:}

All cases of lower thoracic and upper lumbar traumatic and pathological spine fractures compressing the cord indicated for surgical treatment (decompression \& fixation).

\section{Exclusion criteria:}

- Patients with spine fractures above level of T8 or below level of L2.

- Comorbidities that would prevent an operative procedure.

All patients were subjected to thorough history taking and clinical examination with special attention to the following points:
1- History:

a- Age and gender.

b- History of trauma (type: Road traffic accidents, falling from height or direct trauma to the back and nature: High velocity or low velocity).

c- History of spontaneous progressive weakness, sphincteric troubles and sensory changes in both lower limbs.

d- History of chronic illness or malignancy.

2- Clinical findings:

a- Assessment of general condition of the patient.

b- Exclusion of other life threatening conditions like thoraco-abdominal injuries and cranial injuries.

c- Orthopedic consultation to exclude musculoskeletal injuries like: Bone fractures or joint dislocations.

d- Assessment of surgical fitness.

e- Neurological examinations:

1- Motor examination including:

A- Power (potent analgesia should be administered before examination to exclude pain limitation of movement).

B- Superficial \& deep reflexes.

2- Presence of sensory affection (anaesthesia with sensory level or hypothesia).

3- Radiological investigations:

- X-Ray thoracolumbar spine with anteroposterior (AP) and lateral views is the first routine images taken in ER to assess spine injuries.

- MRI of the thoracolumbar spine were performed for all patients to assess the neural elements with good visualization of neural canal components, intervertebral discs injuries and assess integrity of ligamentous component.

- CT thoracolumbar spine were done for all cases with axial and sagittal reconstruction images through the lower dorsal and upper lumbar spine, it provides accurate details of bony anatomy, diameter of bony canal to assess degree of stenosis and allows measurement of the length of the screws that will be utilized in the operation.

4- Surgical procedures:

Patients were classified in two groups.

Group A: 15 patients were operated upon via posterior approach by pedicular screws fixation and decompressive laminectomy. 
Group B: 15 patients were operated upon via anterolateral approach by decompressive corpectomy and fusion by grafting and fixation.

5- Postoperative treatment:

- Medical treatment: Antibiotics, analgesics, gastric protecting drugs, I.V fluids and neurotropic drugs were routinely used for all the patients.

- Physiotherapy: All patients with LL weakness were referred to physiotherapy for 3 months or till improvement of motor power to normal.

- Bladder training: All patients with sphincteric dysfunction were conducted to bladder training by scheduled clamping of the urinary catheter under supervision of our colleagues of urological surgery.

6- Follow-up and outcome:

a- Full neurological examination was performed to all patients to detect improvement or deterioration of the neurological condition.

b- Improvement of back pain were assessed.

c- Post-operative imaging by X-ray and CT of thoracolumbar spine to assess decompression of the canal, alignment of vertebral column and ensuring good placement of fixation system.

d- Patients were discharged after stabilization of their condition with follow-up after 21 days and three months in outpatient clinic.

\section{Statistical analysis:}

- Data were collected and coded to facilitate data manipulation and double entered into Microsoft Access and data analysis was performed using SPSS software version 18 in windows 7 .

- Simple descriptive analysis in the form of numbers and percentages for qualitative data, and arithmetic means as central tendency measurement, standard deviations as measure of dispersion for quantitative parametric data, and inferential statistic test:

\section{- For quantitative parametric data:}

- In-depended student $t$-test used to compare measures of two independent groups of quantitative data.

- Paired $t$-test in comparing two dependent quantitative data.

\section{- For qualitative data:}

- Chi square test to compare two of more than two qualitative groups.
- Mc-Nemartest for paired dependent qualitative data.

- The $p$-value $<0.05$ was considered the cut-off value for significance.

\section{Results}

Table illustrates that there is no statistically significant difference with $p$-value $>0.05$ between two study procedures as regards age and sex distribution which indicated proper matching between both procedures.

Table (1): Comparisons of demographic characters in different study procedures.

\begin{tabular}{|c|c|c|c|c|c|c|}
\hline \multirow{3}{*}{$\begin{array}{l}\text { Variables } \\
\text { Age (years) }\end{array}$} & \multicolumn{4}{|c|}{ Procedure } & \multirow[b]{2}{*}{$\begin{array}{c}p- \\
\text { value }\end{array}$} & \multirow[b]{2}{*}{ Sig. } \\
\hline & \multicolumn{2}{|c|}{$\begin{array}{c}\text { Posterior fixation } \\
\& \text { laminectomy }\end{array}$} & \multicolumn{2}{|c|}{$\begin{array}{l}\text { Corpectomy \& } \\
\text { lateral fixation } \\
\end{array}$} & & \\
\hline & 38.5 & 12.4 & 40.8 & 12.4 & 0.6 & NS \\
\hline \multicolumn{7}{|l|}{ Sex: } \\
\hline Male & 8 & $53.3 \%$ & 9 & $60 \%$ & 0.9 & NS \\
\hline Female & 7 & $46.7 \%$ & 6 & $40 \%$ & & \\
\hline
\end{tabular}

Table illustrates that there is no statistically significant difference with $p$-value $>0.05$ between two study procedures as regards level of fractures which indicated proper matching between both procedures.

Table (2): Comparisons of fractures level in different study groups.

\begin{tabular}{|c|c|c|c|c|c|c|}
\hline \multirow{3}{*}{ Variables } & \multicolumn{4}{|c|}{ Procedure } & \multirow{3}{*}{$\begin{array}{c}p- \\
\text { value }\end{array}$} & \multirow{3}{*}{ Sig. } \\
\hline & \multicolumn{2}{|c|}{$\begin{array}{l}\text { Posterior fixation } \\
\& \text { laminectomy }\end{array}$} & \multicolumn{2}{|c|}{$\begin{array}{l}\text { Corpectomy \& } \\
\text { lateral fixation }\end{array}$} & & \\
\hline & No. & $\%$ & No. & $\%$ & & \\
\hline T9 & 1 & 6.7 & 0 & 0 & 0.61 & NS \\
\hline T10 & 1 & 6.7 & 2 & 13.3 & & \\
\hline T10-11 & 0 & 0 & 1 & 6.7 & & \\
\hline $\mathrm{T} 11$ & 1 & 6.7 & 2 & 13.3 & & \\
\hline $\mathrm{T} 12$ & 5 & 33.3 & 6 & 40 & & \\
\hline L1 & 7 & 46.7 & 4 & 26.7 & & \\
\hline
\end{tabular}

Table illustrates that there is no statistically significant difference with $p$-value $>0.05$ between two study procedures as regards radiological finding which indicated proper matching between both procedures.

Table (3): Comparisons of radiological finding in different study procedures

\section{Procedure}

\begin{tabular}{|c|c|c|c|c|c|c|}
\hline & \multicolumn{2}{|c|}{$\begin{array}{l}\text { Posterior fixation } \\
\text { \& laminectomy }\end{array}$} & \multicolumn{2}{|c|}{$\begin{array}{l}\text { Corpectomy \& } \\
\text { lateral fixation }\end{array}$} & \multirow[t]{2}{*}{$\begin{array}{c}p- \\
\text { value }\end{array}$} & \\
\hline & No. & $\%$ & No. & $\%$ & & \\
\hline Burst & 13 & 86.7 & 12 & 80 & 1 & NS \\
\hline Pathological & 2 & 13.3 & 3 & 20 & & \\
\hline
\end{tabular}




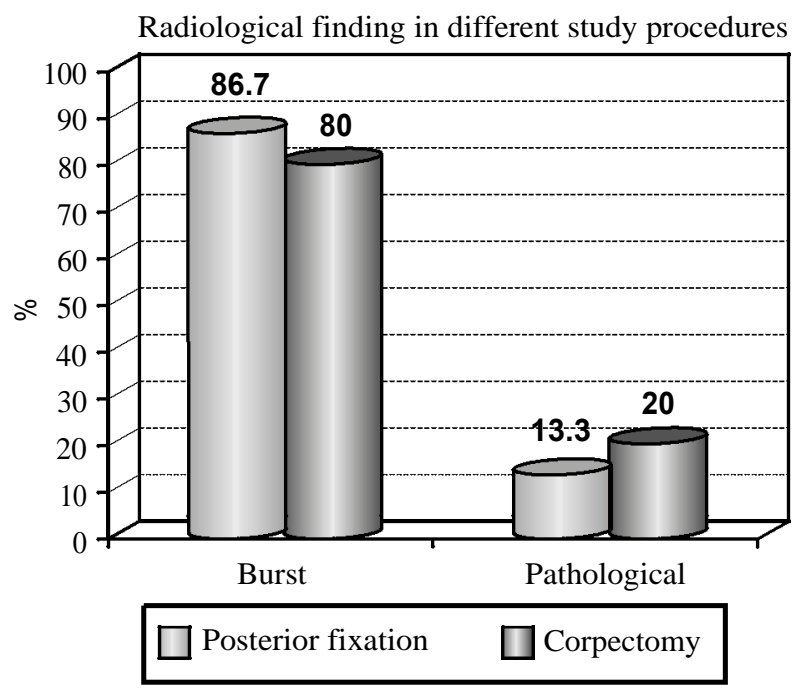

Fig. (1)

Table illustrates that there is no statistically significant difference with $p$-value $>0.05$ between two study procedures as regards preoperative affection of motor and sphencteric dysfunction and grade of motor paralysis which indicated proper matching between both procedures before intervention.

Table (4): Comparisons of pre-operative evaluation in different study procedures.

\begin{tabular}{|c|c|c|c|c|c|c|}
\hline \multirow{3}{*}{ Variables } & \multicolumn{4}{|c|}{ Procedure } & \multirow{3}{*}{$\begin{array}{c}p- \\
\text { value }\end{array}$} & \multirow{3}{*}{ Sig. } \\
\hline & \multicolumn{4}{|c|}{$\begin{array}{l}\text { Posterior fixation Corpectomy \& } \\
\& \text { laminectomy lateral fixation }\end{array}$} & & \\
\hline & No. & $\%$ & No. & $\%$ & & \\
\hline \multicolumn{7}{|l|}{ Sphincteric } \\
\hline \multicolumn{7}{|l|}{ dysfunction: } \\
\hline Yes & 11 & 73.3 & 11 & 73.3 & 1 & NS \\
\hline No & 4 & 26.7 & 4 & 26.7 & & \\
\hline \multicolumn{7}{|l|}{ Motor } \\
\hline \multicolumn{7}{|l|}{ dysfunction: } \\
\hline Yes & 15 & 100 & 15 & 100 & - & - \\
\hline No & 0 & 0 & 0 & 0 & & \\
\hline \multicolumn{7}{|c|}{ Grades of MP: } \\
\hline Grade 0 & 5 & 33.3 & 8 & 53.3 & 0.8 & NS \\
\hline Grade I & 1 & 6.7 & 1 & 6.7 & & \\
\hline Grade II & 2 & 13.3 & 2 & 13.3 & & \\
\hline Grade III & 3 & 20 & 1 & 6.7 & & \\
\hline Grade IV & 4 & 26.7 & 3 & 20 & & \\
\hline
\end{tabular}

Table illustrates that there is no statistically significant difference with $p$-value $>0.05$ between two study procedures as regards occurrence of postoperative complications which indicated that both procedures were safe with almost no complications.
Table (5): Comparisons of post-operative complications in different study procedures.

\begin{tabular}{|c|c|c|c|c|c|c|}
\hline \multirow{3}{*}{$\begin{array}{l}\text { Post-operative } \\
\text { complications }\end{array}$} & \multicolumn{4}{|c|}{ Procedure } & \multirow{3}{*}{$\begin{array}{c}p- \\
\text { value }\end{array}$} & \multirow{3}{*}{ Sig } \\
\hline & \multicolumn{2}{|c|}{$\begin{array}{c}\text { Posterior } \\
\text { fixation \& } \\
\text { laminectomy }\end{array}$} & \multicolumn{2}{|c|}{$\begin{array}{l}\text { Corpectomy } \\
\text { \& lateral } \\
\text { fixation }\end{array}$} & & \\
\hline & No. & $\%$ & No. & $\%$ & & \\
\hline Yes & 1 & 6.7 & 2 & 13.3 & 1 & NS \\
\hline No & 14 & 93.3 & 13 & 86.7 & & \\
\hline
\end{tabular}

Table illustrates that there is no statistically significant difference with $p$-value $>0.05$ between two study procedures as regards mean grades of MP which indicated proper matching between both procedures before intervention with mean of MP grade between grade I, and II and also both procedure achieve same outcome and improvement with increase the grade to be between grade II, and III.

Table (6): Comparisons of pre and post-operative MP grades in different study procedures.

\begin{tabular}{lccccccc}
\hline & \multicolumn{5}{c}{ Procedure } & & \\
\cline { 2 - 3 } $\begin{array}{l}\text { Grade of MP } \\
\text { operation }\end{array}$ & $\begin{array}{c}\text { Posterior } \\
\text { fixation \& } \\
\text { laminectomy }\end{array}$ & & $\begin{array}{c}\text { Corpectomy } \\
\text { \& lateral } \\
\text { fixation }\end{array}$ & $\begin{array}{c}p \text { - } \\
\text { value }\end{array}$ & Sig. \\
\cline { 2 - 3 } & Mean & SD & & Mean & SD & & \\
\hline Before operation & 2 & 1.6 & & 1.3 & 1.6 & 0.3 & NS \\
After operation & 2.5 & 1.9 & & 2.1 & 2.2 & 0.8 & NS \\
\hline
\end{tabular}



Fig. (2) 
Table illustrates that there is no statistically significant difference with $p$-value $>0.05$ between two study procedures as regards improvement of sphincteric, motor functions and grades of MP which indicated that both procedure achieve same outcome.

Table (7): Comparisons of operative outcomes in different study procedures.

\begin{tabular}{|c|c|c|c|c|c|c|}
\hline \multirow{3}{*}{ Variables } & \multicolumn{4}{|c|}{ Procedure } & \multirow{3}{*}{$\begin{array}{c}p- \\
\text { value }\end{array}$} & \multirow{3}{*}{ Sig } \\
\hline & \multicolumn{4}{|c|}{$\begin{array}{l}\text { Posterior fixation Corpectomy \& } \\
\& \text { laminectomy lateral fixation }\end{array}$} & & \\
\hline & No. & $\%$ & No. & $\%$ & & \\
\hline \multirow{2}{*}{\multicolumn{7}{|c|}{$\begin{array}{l}\text { Sphincteric } \\
\text { improvement: }\end{array}$}} \\
\hline & & & & & & \\
\hline Yes & 3 & 27.3 & 5 & 45.5 & 0.6 & NS \\
\hline No & 8 & 72.7 & 6 & 54.5 & & \\
\hline \multicolumn{7}{|l|}{ Motor } \\
\hline \multicolumn{7}{|l|}{ improvement: } \\
\hline Yes & 8 & 53.3 & 8 & 53.3 & 1 & NS \\
\hline No & 7 & 46.7 & 7 & 46.7 & & \\
\hline \multicolumn{7}{|l|}{ Grades of $M P$} \\
\hline \multicolumn{7}{|c|}{ after operation: } \\
\hline Grade 0 & 5 & 33.3 & 7 & 46.7 & 0.4 & NS \\
\hline Grade I & 0 & 0 & 1 & 6.7 & & \\
\hline Grade II & 2 & 13.3 & 0 & 0 & & \\
\hline Grade III & 1 & 6.7 & 1 & 6.7 & & \\
\hline Grade IV & 5 & 33.3 & 2 & 13.3 & & \\
\hline Grade V & 2 & 13.3 & 4 & 26.7 & & \\
\hline
\end{tabular}

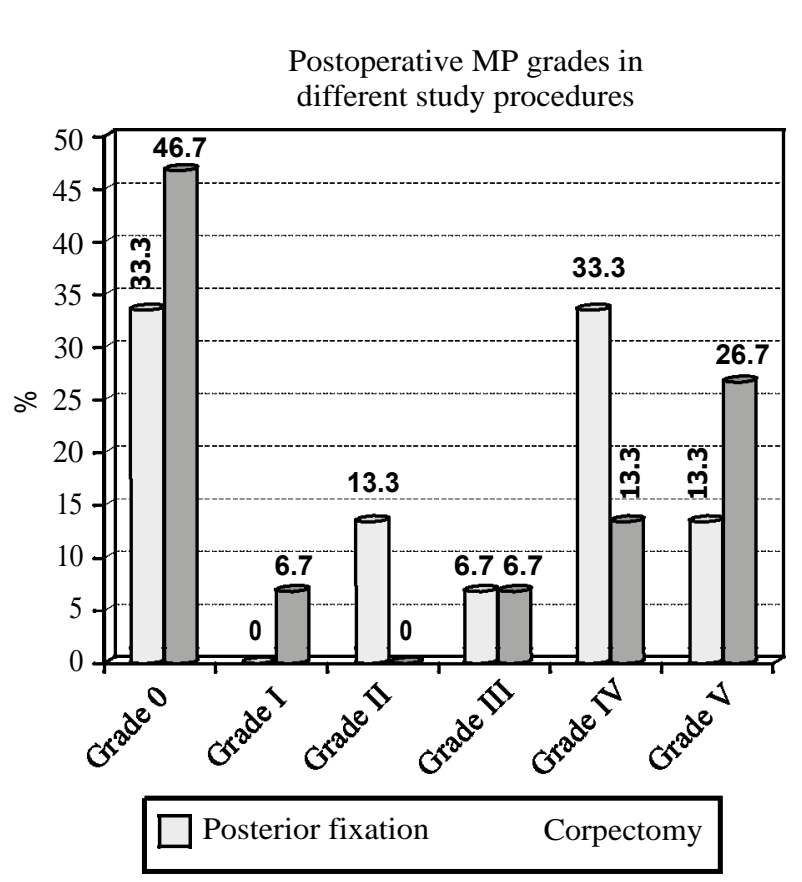

Fig. (3)

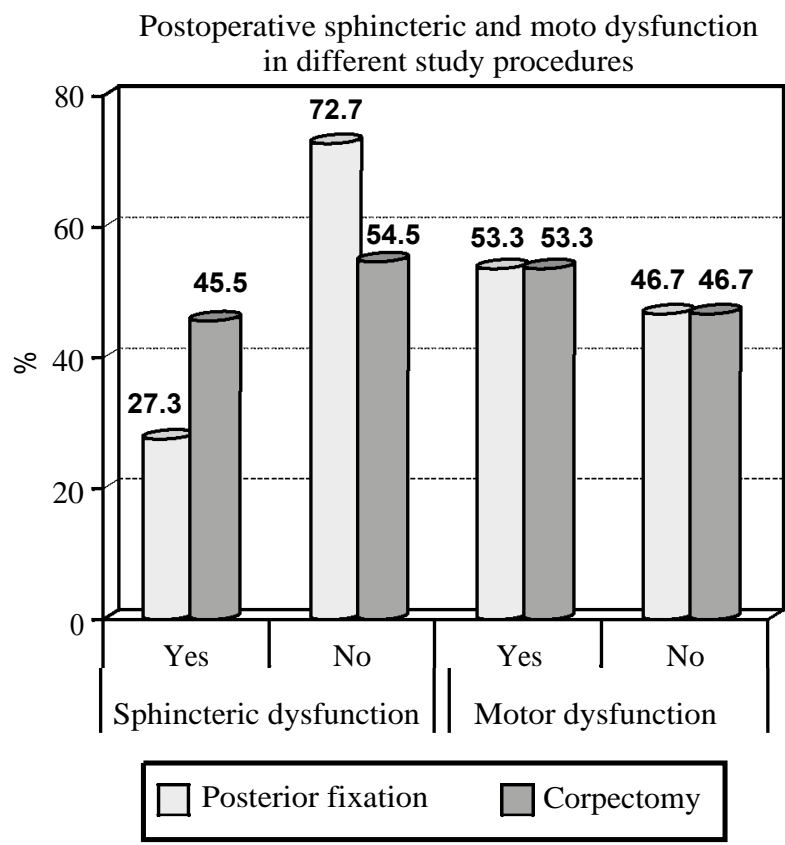

Fig. (4)

Table illustrates that there is no statistically significant difference with $p$-value $>0.05$ between two study procedures as regards duration of sphincteric, motor functions improvement which indicated that both procedure achieve same outcome.

Table (8): Comparisons of duration of improvement in different study procedures.

\begin{tabular}{lcccccc}
\hline & \multicolumn{4}{c}{ Procedure } & & \\
\cline { 2 - 4 } $\begin{array}{l}\text { Duration of } \\
\text { improvement } \\
\text { (weeks) }\end{array}$ & $\begin{array}{c}\text { Posterior } \\
\text { fixation \& } \\
\text { laminectomy }\end{array}$ & $\begin{array}{c}\text { Corpectomy } \\
\text { \& lateral } \\
\text { fixation }\end{array}$ & $\begin{array}{c}p \text { - } \\
\text { value }\end{array}$ & Sig. \\
\cline { 2 - 4 } & \multicolumn{2}{c}{ Mean SD } & \multicolumn{2}{c}{ Mean SD } & & \\
\hline Sphincteric & 4 & 3.6 & 8.6 & 4.9 & 0.1 & NS \\
Motor & 10 & 2.8 & 6.7 & 3.9 & 0.3 & NS \\
\hline
\end{tabular}

Duration of sphincteric and motor improvement in different study procedures



Fig. (5) 
Table illustrates that there is statistically significant difference with $p$-value $<0.05$ in MP grading in each study procedure with statistical significant improvement and increase in mean grade from 2 to 2.5 among Posterior fixation \& laminectomy procedure and from 1.3 to 2.1 among Corpectomy \& Lateral fixation.

Table (9): Comparisons of pre and post-operative MP grades in each study procedures.

\begin{tabular}{|c|c|c|c|c|}
\hline \multirow{3}{*}{$\begin{array}{l}\text { Grade of MP } \\
\text { operation }\end{array}$} & \multicolumn{4}{|c|}{ Procedure } \\
\hline & \multicolumn{2}{|c|}{$\begin{array}{l}\text { Posterior fixation } \\
\& \text { laminectomy }\end{array}$} & \multicolumn{2}{|c|}{$\begin{array}{l}\text { Corpectomy \& } \\
\text { lateral fixation }\end{array}$} \\
\hline & Mean & SD & Mean & SD \\
\hline Before operation & 2 & 1.6 & 1.3 & 1.6 \\
\hline After operation & 2.5 & 1.9 & 2.1 & 2.2 \\
\hline$p$-value & \multicolumn{2}{|c|}{$<0.001$} & \multicolumn{2}{|c|}{0.003} \\
\hline Sig. & \multicolumn{2}{|c|}{ HS } & \multicolumn{2}{|c|}{ S } \\
\hline
\end{tabular}

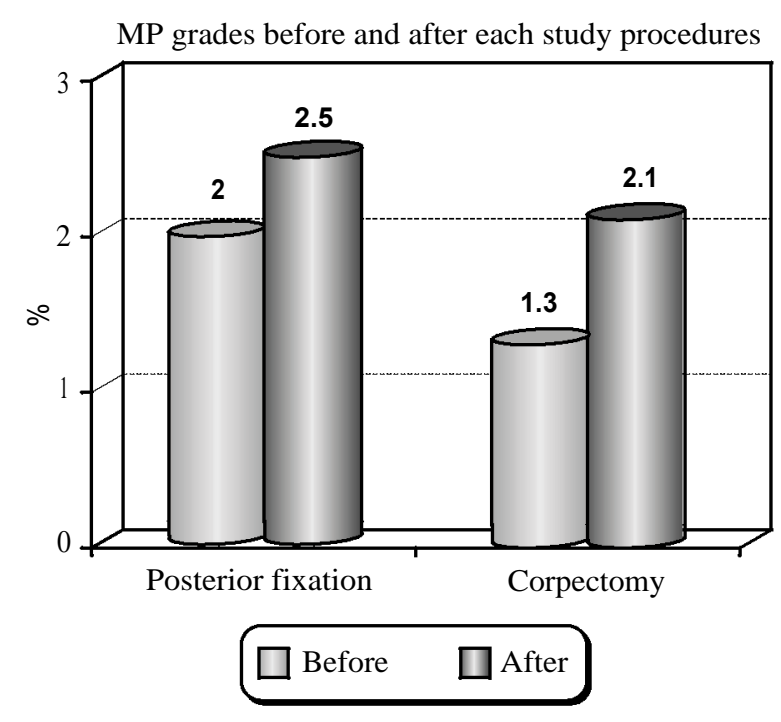

Fig. (6)

Table illustrates that there is statistically significant difference with $p$-value $<0.05$ in motor function improvement in each study procedure with statistical significant improvement and decrease in motor dysfunction percentage from $100 \%$ to $46.7 \%$ among both Posterior fixation \& laminectomy and Corpectomy \& Lateral fixation procedures.

Table (10): Comparisons of motor improvement in each study procedures.

\begin{tabular}{|c|c|c|c|c|}
\hline \multirow{3}{*}{$\begin{array}{l}\text { Motor } \\
\text { dysfunction }\end{array}$} & \multicolumn{4}{|c|}{ Procedure } \\
\hline & \multicolumn{2}{|c|}{$\begin{array}{l}\text { Posterior fixation } \\
\& \text { laminectomy }\end{array}$} & \multicolumn{2}{|c|}{$\begin{array}{l}\text { Corpectomy \& } \\
\text { lateral fixation }\end{array}$} \\
\hline & No. & $\%$ & No. & $\%$ \\
\hline Before operation & 15 & 100 & 15 & 100 \\
\hline After operation & 7 & 46.7 & 7 & 46.7 \\
\hline$p$-value & \multicolumn{2}{|c|}{0.001} & \multicolumn{2}{|c|}{0.001} \\
\hline Sig. & \multicolumn{2}{|c|}{ HS } & \multicolumn{2}{|c|}{ HS } \\
\hline
\end{tabular}

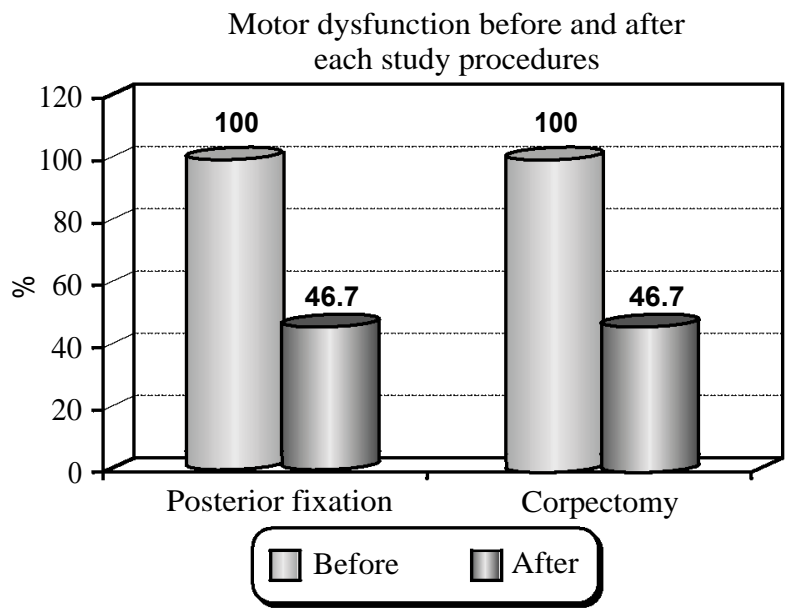

Fig. (7)

Table illustrates that there is no statistically significant difference with $p$-value $>0.05$ in sphincteric function improvement in among Posterior fixation \& laminectomy. On the other handthere is statistically significant difference with $p$-value $<0.05$ in sphincteric function improvement with statistical significant improvement and decrease in sphincteric dysfunction percentage from $73.3 \%$ 40\% among Corpectomy \& Lateral fixation procedure.

Table (11): Comparisons of sphencteric improvement in each study procedures.

\begin{tabular}{lccccc}
\hline & \multicolumn{4}{c}{ Procedure } \\
\cline { 2 - 3 } $\begin{array}{l}\text { Sphencteric } \\
\text { dysfunction }\end{array}$ & $\begin{array}{c}\text { Posterior fixation } \\
\text { \& laminectomy }\end{array}$ & & \multicolumn{2}{c}{$\begin{array}{c}\text { Corpectomy \& } \\
\text { lateral fixation }\end{array}$} \\
\cline { 2 - 3 } \cline { 5 - 7 } & No. & $\%$ & & No. & $\%$ \\
\hline Before operation & 11 & 73.3 & & 11 & 73.3 \\
After operation & 8 & 53.3 & & 6 & 40 \\
$p$-value & \multicolumn{2}{c}{0.3} & & \multicolumn{2}{c}{0.03} \\
Sig. & \multicolumn{2}{c}{ NS } & & \multicolumn{2}{c}{ S } \\
\hline
\end{tabular}

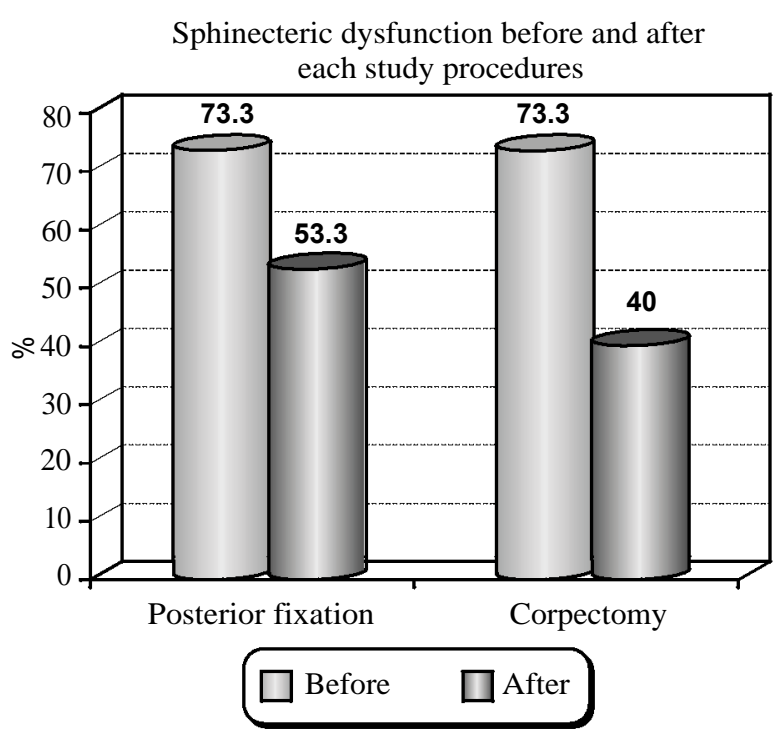

Fig. (8) 


\section{Discussion}

Thoracic and lumbar compressive spine fractures are highly prevalent, representing nearly $90 \%$ of all traumatic spine injuries. 52\% of these injuries occurred at thoracolumbar junction (T11-L1). Anteroposterior and lateral conventional radiographs of the thoracic and lumbar spine are the most basic imaging modalities. CT is better than conventional radiography in detection of thoracic and lumbar spine injuries.

Unless contraindicated, MRI should be considered in all cases with neurologic injury and where assessment of posterior ligamentous complex is necessary. The decision to treat a fracture surgically with internal fixation with or without neural element decompression, or non-surgically with a brace depends on several factors. Indications of surgery are clear in some cases, but controversial in others [11-15]

Thoracolumbar burst \& pathological fractures can be treated via different approaches: Anterior, posterior or a combination of the two approaches in some special cases. Theoretically, the anterior approach offers some benefits such as better canal decompression $[\mathbf{1 6 , 1 7 ]}$. This approach provides better exposure of the fractured vertebrae, enabling a more thorough decompression [18]. In contrast, the posterior approach can only support indirect decompression [19]. Therefore, good canal remodeling after canal encroachment occurred in the anterior approach group just as all the included studies concerning this parameter.

Our study included 30 patients complaining of back pain and different degrees of neurological deficits in both lower limbs and spincteric troubles due to lower thoracic and upper lumbar compressive spine fractures. The patients were classified in two groups: The first group 15 patients with mean age of 38.5 years old and second group of 40.8 years old. In first group, 8 patients were males $(53.3 \%)$ and 7 patients were females $(46.7 \%)$. In second group, 9 patients were males $(60 \%)$ and 6 patients were females $(40 \%)$. Lin et al., [20] mentioned that in their study there were 64 patients with thoracolumbar burst fractures classified in two groups: First group with mean age of 39 years old and second group with mean age of 38 years old. In first group, there were 16 male patients $(50 \%)$ and 16 female patients $(50 \%)$. In second group, there were 14 male patients $(43.75 \%)$ and 18 female patients $(56.25 \%)$ which is similar to our study indicating good matching with no selection of cases.
In contrary to our study, Denisa et al., [21] mentioned that in their study of 43 patients with thoracolumbar fractures, patients were classified into two groups: A first group of 27 patients: 19 patients were males $(70.3 \%)$ and 8 patients were females $(29.7 \%)$ and a second group of 16 patients: 11 of them were males $(68.75 \%)$ and only 5 female patients $(31.25 \%)$ which showing predominance of male gender in Denisa study.

In our study, causes of fractures were trauma in 25 patients: 13 in the first group (86.7\%) and 12 in the second group (80\%) and pathological in 5 patients: $2(13.3 \%)$ in first group and 3 in second group (20\%). Mode of trauma in traumatized patients was road traffic accidents in 14 patients; 8 in first group (61.5\%) and 6 in the second group $(50 \%)$ and falling from height in 11 patients; 5 in first group (38.5\%) and 6 in second group (50\%). In contrary to our study, Sasso et al., [22] reported that in their series of 53 patients; all patients were traumatic with no pathological fractures included in their study.

Our study included various levels of fractures, in first group there were: One case with T9 fracture, one case with T10 fracture, one case with T11 fracture, 5 cases with T12 fracture and 7 cases with $\mathrm{L} 1$ fracture while in second group 2 cases with $\mathrm{T} 10$ fractures, one case with $\mathrm{T}$ 10-11 fracture, 6patients with T12 fracture and 4 cases with L1 fracture showing majority of fractures at $\mathrm{T} 12$ and L1 levels. Similar to our study, Hitchon et al., [23] said that in their study of 63 patients with lower thoracic and upper lumbar spine fractures classified in 2 groups. First group of 25 patients; one patient with T 11 fracture, 3 patients with T12 fractures, 12 patients with $\mathrm{L} 1$ fracture and 9 patients with L2 fracture and a second group of 38 patients showed one patient with $\mathrm{T} 11$ fracture, 13 patients with T12 fracture, 18 patients with L 1 fracture and 6 patients with L2 fractures which correlate for majority of injuries at T12 and L1 levels like our study except for presence of L2 fracture in this study which was excluded in our thesis.

In our study, 11 patients with sphincteric dysfunction in each group (73.3\%) and 4 patients with normal sphincteric functions (26.7\%), but motor affection was evident in all patients. In first group, 5 patients were complete paraplegic (Grade 0) (33.3\%), one patient (GI) (6.7\%), 2 patients (G2) (13.3\%), 3 patients (GIII) (20\%) and 4 patients (GIV) $(26.7 \%)$. In second group, 8 patients were complete paraplegic with motor power grade 0 (53.3\%), one patient was grade I (6.7\%), 2 patients were grade II (13.3\%), one patient was grade III $(6.7 \%)$ and 3 patients were grade IV (20\%). 
In first group, the mean motor power preoperative was 2 and mean motor power in second group preoperative was 1.3. The postoperative results after 3 months showed motor power of 2.5 in first group and 2.1 in second group which showed no superiority of any approach over the other in our study in regaining motor power or ability to walk in paraplegic and severe paraparetic patients which was reported also by Xu et al., in their study. On the other hand, there was a significant difference in the outcome of sphincteric function improvement in second group (anterior approach) by decrease in sphincteic dysfunction percentage from $73.3 \%$ preoperative to $40 \%$ postoperative while in the first group, the improvement of sphincteric dysfunction which was evident in $73.3 \%$ preoperative decreased to $53.3 \%$ postoperative showing superiority of anterior approach over posterior approach in improving sphincteric dysfunction in early postoperative few months.

Interestingly, although some authors have reported that compared to the posterior approach, the anterior approach provides better decompression of thoracolumbar fractures, which [22,24].

The relationship between the extent of canal encroachment and neurological function has been studied; although concerns have been raised regarding inadequate spinal canal remodeling after treatment via the posterior approach, there is no evident association between the percentage of canal encroachment and clinical symptoms [25,26]. Generally, the most important purpose of the surgical management of thoracolumbar fractures is to minimize the change in the patients' lives.

Our review showed that although the anterior approach was associated with better canal remodeling, it was not associated with a greater improvement in Frankel scores or a higher incidence of return to work. This is similar to reports that recovery of neurological function did not depend on the extent of spinal decompression and canal encroachment $[25,27]$.

On critical evaluation of the included trials, we found that there were no difference in complication rate between first and second group, and our complications were related to spine surgery in general like dural tear or superficial wound infection regardless of the approach anteriorly or posteriorly, or due to inability to walk and prolonged recumbancy like DVT. In contrary to our study, Lin et al., [20] reported many more complications in the anterior approach group than in the posterior group, including twenty-seven cases of hemo -pneumoth- orax, two cases of respiratory tract infection, three cases of intercostal neuralgia and thirteen cases of abdominal distension and constipation. In the study conducted by Wood et al., [24] there were seventeen "events" in the posterior approach group, including six cases of instrument removal, two cases of wound dehiscence, two cases of instrumentation /bone failure, two urinary tract infections, two cases of instrument breakage, one deep wound infection, one case of pseudarthrosis and one case of seroma. Because these two studies markedly differed from the other included studies.

In addition, we did not find significant differences in operative time, blood loss and cost between the two groups. The anterior approach group was associated with longer operative times due to lack of experience with this approach in first few cases but after many cases there was no significant difference between duration of anterior versus posterior approach. Higher costs were associated with anterior approach due to the special requirements of anaethesia due to single lung ventilation and the need for titanium mesh or expandable thoracic or lumbar cage.

\section{Conclusion:}

Good clinical evaluation of every case with exclusion of life threatening conditions and stabilization of the general condition of the patient is mandatory before proceeding in the definitive management of the spinal pathology.

$\mathrm{X}$-rays AP and lateral views, CT and MRI on the affected level are mandatory to assess affected vertebrae, spinal cord, nerve roots, epidural space and intervertebral discs with good visualization of posterior ligamentous complex injuries.

The results of this study showed that in the surgical management of thoracolumbar burst and pathological fractures, the anterolateral approach was not significantlybetter than the posterior approach in terms of significant recovery of neurological function, return to work and maintaining normal life activities. To some extent the anterior approach was better than posterior approach in rapid improvement of sphincteric control in patients with incomplete cord injury with sphincteric troubles. On the other hand, posterior approach was a valid approach with easy preparation and available instrumentation under current causality within few hours from the insult which serves us in emergent cases. Therefore selection of the appropriate approach must be made cautiously and on a case-bycase basis. 


\section{References}

1- ALANANY A., YAZICI M., ACAROGLU E., et al.: Course of nonsurgical management of burst fractures with intact posterior ligamentous complex: An MRI study. Spine, 29: 2425-2431, 2004.

2- FINKELSTEIN J.A., WAI E.K., JACKSON S.S., et al.: single-level fixation of flexion destraction injuries. J. Spinal Disord Tech., 16: 236-242, 2003.

3- ONER F.C., RAMOS L.M., SIMERMACHER R.K., et al.: Classification of thoracic and lumbar spine fractures: Problems of reproductibility. A study of 53 patients using CT and MRI. EUR Spine J., 11: 235-245, 2002.

4- THOMAS K.C., BAILY C.S., DVORAK M.F., et al.: Comparison of operative and non-operative treatment for thoracolumbar burst fractures in patients without neurological deficit: A systematic review. J. Neurosurg., 4: 351$358,2006$.

5- VACCARO A., LIM M., HURLBERT R., et al.: Surgical decision making for unstable thoracolumbar spine injuries: results of a consensus panel review by the Spine Trauma Study Group. J. Spinal Disord Tech., 19: 1-10, 2006.

6- WOOD K., BUTTERMANN G., MEHBOD A., et al.: Operative compared with nonoperative treatment of thoracolumbar burst fracture without neurological deficit: A prospective, randomized study. J. Bone Joint Surg. Am., 85: 773-781, 2003.

7- WOOD K.B., KHANNA G., VACCARO A.R., et al.: Assessment of two thoracolumbar fractures classification systems as used by multiple surgeons. G Bone Joint Surg. Am., 87: 1423-1429, 2005.

8- FOUNTAIN S.S.: A single staged combined surgical approach for vertebral resections. J. Bone Joint Surg. Am., 61: 1011-1017, 1979.

9- KEMP H.B., JACKSON J.W., JEREMIAH J.D. and COOK J.: Anterior fusion of the spine for infective lesions in adults. J. Bone Joint Surg. Br., 55: 715-734, 1973.

10- KIRKALDY-WILLIS W.H. and THOMAS T.G.: Anterior approaches in the diagnosis and treatment of infections of vertebral bodies, 47A: 87-110, 1965.

11-DASHTI H., LEE H.C., KARAIKOVIC E.E. and GAINES R.W.: Decision making in dorsolumbar fractures. Neurology India, 53: Issue 4, 2005.

12- DENIS F.: Spinal Instability As Defined by the ThreeColumn Spine Concept in Acute Spinal Trauma. Clin. Orthop., 189: 65-76, 1984.

13- WILLIAMS S.K.: Thoracic and lumbar spine injuries. In: Herkowitz H.N., Garfin S.R., Eismont F.J., et al. In: Daniel Pepper and Beth LoGiudice (eds). The spine (sixth edition). Elsevier Saunders, 1363-1389, 2011.

14- BAGLEY L.J.: Imaging of spinal trauma. Radiol. Clin. North Am., 44: 1-12, 2006.

15- HARRIS J.H. Jr.: Radiographic evaluation of spinal trauma. Orthop. Clin. Nroth Am., 17: 75-86, 1986.
16- KANEDA K., TANEICHI H., ABUMI K., HASHIMOTO T., SATOH S. and FUJIYA M.: Anterior decompression and stabilization with the Kaneda device for thoracolumbar burst fractures associated with neurological deficits. J. Bone Joint Surg Am., 79 (1): 69-83, 2007.

17- FALAVIGNA A., RIGHESSO N.O., POLESSO M.A and FRANCESCHINI P.R.: Anterior approach in patients with traumatic compression fracture type of thoracolumbar spine (T11-L2). Arq Neuropsiquiatr, 65 (3): 906-91, 2007.

18- KIM H.S., LEE S.Y., NANDA A., KIM J.Y., PARK J.O., MOON S.H., LEE H.M., KIM H.J., WEI H. and MOON E.S.: Comparison of surgical outcomes in thoracolumbar fractures operated with posterior constructs having varying fixation length with selective anterior fusion. Yonsei Med J., 50 (4): 546-554, 2009.

19- KUNER E.H., KUNER A., SCHLICKEWEI W. and MULLAJI A.B.: Ligamentotaxis with an internal spinal fixator for thoracolumbar fractures. J. Bone Joint Surg. Br., 76 (1): 107-112, 1994

20- LIN B., CHEN Z.W., GUO Z.M., LIU H. and YI Z.K.: Anterior approach versus posterior approach with subtotal corpectomy, decompression, and reconstruction of spine in the treatment of thoracolumbar burst fractures: A prospective randomized controlled study. J. Spinal Disord Tech., doi:10.1097/BSD. 0b013e3182204c53, 2011.

21- DANISA O.A., SHAFFREY C.I., JANE J.A., WHITEHILL R., WANG G.J., SZABO T.A., HANSEN C.A., SHAFFREY M.E. and CHAN D.P.: Surgical approaches for the correction of unstable thoracolumbar burst fractures: A retrospective analysis of treatment outcomes. J. Neurosurg., 83 (6): 977-983, 1995.

22- SASSO R.C. RENKENS K., HANSON D., REILLY T., McGUIRE R.J. and BEST N.M.: Unstable thoracolumbar burst fractures: Anterior-only versus short-segment posterior fixation. J. Spinal Disord Tech., 19 (4): 242-248, 2006.

23- HITCHON P.W., TORNER J., EICHHOLZ K.M. and BEELER S.N.: Comparison of anterolateral and posterior approaches in the management of thoracolumbar burst fractures. J. Neurosurg. Spine, 5 (2): 117-125, 2006.

24- WOOD K.B., BOHN D. and MEHBOD A.: Anterior versus posterior treatment of stable thoracolumbar burst fractures without neurologic deficit: A prospective, randomized study. J. Spinal Disord Tech., 18 (Suppl): 15-23, 2005.

25- DAI L.Y., WANG X.Y. and JIANG L.S.: Neurologic recovery from thoracolumbar burst fractures: Is it predicted by the amount of initial canal encroachment and kyphotic deformity? Surg. Neurol., 67 (3): 232-237, 238, 2007.

26- TROPIANO P., HUANG R.C., LOUIS C.A., POITOUT D.G. and LOUIS R.P.: Functional and radiographic outcome of thoracolumbar and lumbar burst fractures managed by closed orthopaedic reduction and casting. Spine, 28 (21): 2459-2465, 2003.

27- McLAIN R.F.: Functional outcomes after surgery for spinal fractures: Return to work and activity. Spine, 29 (4): 470-477, 2004. 


 لعلاج كسور الفقرات الصدرية التهل السفلى والقطنية العامى العليا}

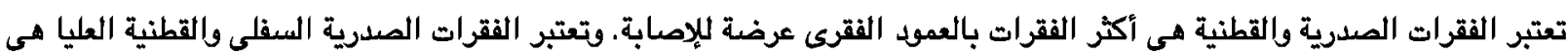

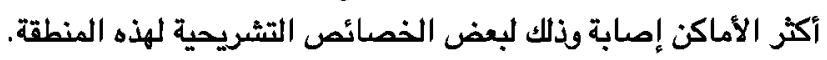

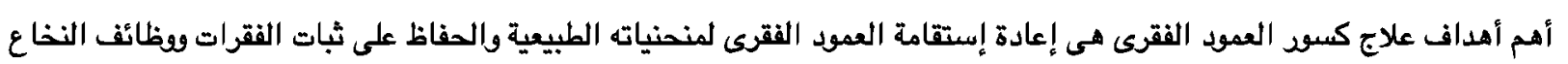

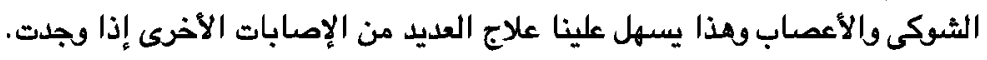

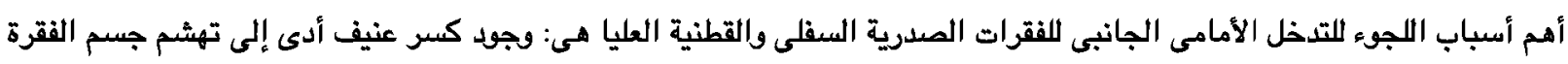


القناة الشوكية.

التخل الخلفى لسكود العمود الفقرى مو أكثر أنقاع التخل إستخداماً بواسطة جراحى العمود الفقرى حيث يعتبر تدخلا معروفاً ويسهل

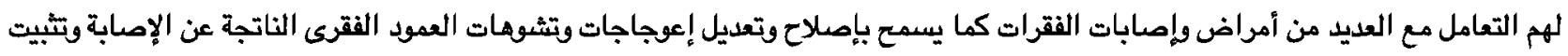



